\title{
PENGARUH STRESS KERJA, KOMITMEN ORGANISASIONAL DAN KEPUASAN KERJA TERHADAP TURNOVER INTENTION PERUSAHAAN OTOMOTIF
}

\author{
IRMA GUSTIANA ANDRIANI \\ STIE Trisakti \\ irma_gustiana@dosen.stietrisakti.ac.id
}

\begin{abstract}
The purpose of this study is to determine the effect of work stress, organizational commitment, and work satisfaction to turnover intention. The object of this research is a company operating in the field of car sales auto parts sales and maintenance of cars. The method used in this research is descriptive method and causality with multiple regression method to test the hypothesis. This research use nonprobability sampling technique with saturation sampling method. Respondents used in this study were 87 active employees. Technique of collecting data by using questionnaire.. The result of the research shows that work stress has significant effect to turnover intention, but organizational commitment and work satisfaction has no significant effectto turnover intention.
\end{abstract}

Keywords: Turnover intention, work stress, organizational commmitment, work satisfaction

\begin{abstract}
Abstrak: Tujuan penelitian adalah untuk mengetahui pengaruh dari variabel stress kerja, komitmen organisasional, dan kepuasan kerja terhadap turnover intention karyawan. Objek dalam penelitian ini adalah perusahaan yang beroperasi di bidang penjualan mobil, spare parts dan perawatan mobil. Metode yang digunakan dalam penelitian ini adalah metode deskriptif dan kausalitas dengan metode regresi berganda untuk menguji hipotesis. Penelitian ini menggunakan teknik nonprobability sampling dengan metode sampling jenuh. Responden yang digunakan dalam penelitian ini adalah 87 karyawan aktif.Teknik pengumpulan data dengan menggunakan kuisioner. Hasil penelitian menunjukkan bahwa stress kerja berpengaruh secara signifikan terhadap kinerja karyawan, tetapi komitmen organisasional dan kepuasan kerja tidak berpengaruh terhadap turnover intention.
\end{abstract}

Kata kunci: Turnover intention, stress kerja, komitmen organisasional, kepuasan kerja

\section{PENDAHULUAN}

Saat ini industri manufaktur mobil di indonesia semakin berkembang pesat dengan peluang yang sangat besar dan terus bertumbuh. Indonesia memiliki industri manufaktur mobil terbesar kedua di Asia Tenggara dan di wilayah ASEAN (setelah Thailand yang menguasai sekitar 50 persen dari produksi mobil di wilayah ASEAN). Salah satu tantangan yang dihadapi dalam industri mobil saat ini adalah bagaimana mengelola sumber daya manusia untuk mempertahankan orang orang terbaik yang telah mereka miliki.

\section{Stress Kerja}

Robbins dan Judge (2015) menyatakan bahwa, stress kerja adalah suatu kondisi ketegangan yang menciptakan adanya ketidakseimbangan fisik dan psikis, yang mempengaruhi emosi, proses pikir, dan kondisi seorang karyawan. Stress yang terlalu besar 
dapat mengancam kemampuan seseorang untuk menghadapilingkungan.Sebagai hasilnya, pada diri karyawan berkembang berbagai macam gejala stress yang dapat mengganggu pelaksanaan kerja mereka (Gaol 2015).Terdapat banyak bukti yang mengidentifikasikan bahwa, intention to leaveakan meningkat jika dalam kondisi kerja suatu individu menghasilkan job stress yang tinggi (Angerer et al., 2015).

Seseorang dapat merespon dan merasakan tingkat stressyang berbeda dengan orang lain meskipun mendapatkan pemicu stress yang sama, alasannya adalah setiap orang memiliki perbedaan tingkatan kemampuanuntuk menghadapi stress. Alasan kedua untuk perbedaan respon stress adalah setiap orang memiliki strategi-strategi yang berbeda dalam menghadapi suatu stress, dimana antara satu strategi mungkin lebih baik daripada strategi yang lain, atau mungkin lebih buruk. Alasan ketiga adalah setiap orang memiliki tingkat resiliansi yang berbeda yaitu merupakan kemampuan seseorang untuk menanggulangi dengan baik saat berhadapan dengan kesengsaraan, dan perubahanperubahan yang signifikan. (Haryanto 2014). Berdasarkan pemaparan diatas, maka hipotesis yang diambil adalah:

$\mathrm{H}_{1}$ Stress Kerja Mempengaruhi Turnover Intention

\section{Komitmen Organisasional}

Robbins dan Judge (2015) menyatakan bahwa, komitmen organisasional ditandai sebagai suatu keadaan dimana seseorang karyawan memihak organisasi tertentu serta tujuan-tujuan dan keinginannya untuk mempertahankan keanggotaan dalam organisasi tersebut.Jadi, keterlibatan pekerjaan yang tinggi berarti memihak pada pekerjaan tertentu seseorang individu,sementara komitmen norganisasional yang tinggi berarti memilhak organisasi yang merekrut individu tersebut. Daft (2015) menyatakan bahwa, komitmen organisasional mengacu pada loyalitas karyawan dan keterlibatan karyawan terhadap organisasi. Dimana karyawan dengan Komitmen Organisasional yang tinggi akan melibatkan organisasi terhadap seluruh aktifitas dan pekerjaan yang dilakukannya dan memunyai keinginan berkontribusi dalam seluruh kegiatan organisasi sehingga tujuan organisai dapat tercapai.

Seorang karyawan bisa saja mempunyai keterikatan emosional dan merasa mempunyai kewajiban terhadap organisasi tetapi karena pertimbangan ekonomi maka ia membutuhkan pekerjaan lain di luar organisasi. Disisi lain, karena sulit mendapatkan alternatif pekerjaan lain maka seorang karyawan tetap bertahan di organisasi sekalipun tidak memiliki keterikatan emosional yang kuat dengan organisasi. Disamping itu komitmen pada organisasi berkembang sebagai hasil dari pengalaman yang berbeda serta memiliki implikasi yang berbeda pula. Oleh karena itu pemahaman yang jelas mengenai hubungan karyawan dengan organisasi maka dalam pengukuran komitmen pada organisasi seharusnya juga merefleksikan ketiga komponen tersebut yaitu affective commitment, continuance commitment dan normative commitment. Berdasarkan pemaparan diatas, maka hipotesis yang diambil adalah:

$\mathrm{H}_{2}$ Komitmen Organisasional mempengaruhi Turnover Intention

\section{Kepuasan Kerja}

Robbins dan Judge (2015) menyatakan bahwa Job Satisfaction merupakan suatu perasaan positif yang karyawan rasakan terhadap pekerjannya.Karyawan yang memiliki tingkat kepuasan kerja yang tinggi mempunyai sikap positif terhadap pekerjannya.Sebalikya, seseorang dengan tingkat job satisfaction yang rendah, memiliki perasaan negatif pada pekerjaannya.Sinambela (2015) menyatakan pekerja yang memiliki job satisfaction yang rendah akan memiliki keinginan yang tinggi 
untuk meninggalkan organisasi, terutama ketika mereka memiliki banyak alternatif pekerjaan lain untuk dituju dan ketika mereka memiliki human capital yang tinggi. Daft (2015) menyatakan bahwa kepuasan kerja di deskripsikan sebagai perasaan positif tentang suatu pekerjaan, sebagai hasil dari evaluasi karakteristik itu sendiri.Evaluasi dari pekerjaan karyawan akan terlihat dari ketuntasan pekerjaan jika karyawan tersebut memiliki sikap yang positif terhadap pekerjannya. Karyawan akan merasakan perasaan tersebut jika pekerjaan yang mereka lakukan cocok dengan kebutuhan dan keinginannya. Seperti ketika kondisi dan reward dalam pekerjaan itu sesuai, mempunyai rekan kerja yang kooperatif dan mempunyai hubungan positif dengan atasan atau supervisor.

Salah satu faktor penyebab timbulnya keingininan seorang pegawai untuk berpindah kerja adalah ketidakpuasan pada tempat kerja sekarang. Penyebab ketidakpuasan tersebut dapat beraneka ragam seperti penghasilan yang rendah, kondisi kerja yang kurang memuaskan, serta hubungan kerja yang tidak harmonis. Hal ini memperlihatkan bahwa ada korelasi antara tingkat kepuasan kerja dengan kuat lemahnya keinginan untuk pindah kerja (Sunyoto 2015). Berdasarkan pemaparan diatas, maka hipotesis yang diambil adalah:

$\mathrm{H}_{3} \quad$ Komitmen Organisasional mempengaruhi Turnover Intention

\section{METODA PENELITIAN}

Penelitian ini menggunakan 87 karyawan yang bekerja pada perusahaan dengan karakteristik sebagai berikut:

Tabel 1 Karakteristik Responden Berdasarkan Jenis Kelamin

\begin{tabular}{cll}
\hline & Frequency & Percent \\
\hline Pria & 51 & 58.6 \\
Wanita & 36 & 41.4 \\
\hline Total & 87 & 100.0 \\
\hline
\end{tabular}

Tabel 2 Karakteristik Responden Berdasarkan Usia

\begin{tabular}{lll}
\hline & Frequency & Percent \\
\hline$<25$ tahun & 26 & 29.9 \\
$25-34$ tahun & 41 & 47.1 \\
$34-44$ tahun & 13 & 14.9 \\
$44-54$ tahun & 5 & 5.7 \\
$>55$ tahun & 2 & 2.3 \\
\hline Total & 87 & 100.0 \\
\hline
\end{tabular}

Tabel 3 Karakteristik Responden Berdasarkan Lama Bekerja

\begin{tabular}{lcc}
\hline & Frequency & Percent \\
\hline$<1$ tahun & 20 & 23.0 \\
1-5 tahun & 38 & 43.7 \\
6-9 tahun & 17 & 19.5 \\
10-14 tahun & 5 & 5.7 \\
$>15$ tahun & 7 & 8.0 \\
\hline Total & 87 & 100.0 \\
\hline
\end{tabular}


Turnover Intentionadalah kecenderungan sikap atau tingkat dimana seorang karyawan memiliki kemungkinan untuk meninggalkan organisasi atau mengundurkan diri secara sukarela dari pekerjaanya. Stress Kerja adalah merupakan kondisi internal yang memengaruhi pegawai serta ditandai dengan ketidakseimbangan fisik dan psikis yang disebabkan oleh faktor lingkungan, faktor organisasi, dan faktor personal. Komitmen Organisasional adalahsuatu sikap setuju seseorang terhadap tujuan dan nilai-nilai organisasi, adanya kemauan kuat untuk memberikan usaha ekstra untuk kepentingan dan keuntungan organisasi, serta keinginan kuat untuk bertahan dan terlibat di dalam organisasi, terlibat dalam kegiatan organisasi dan melakukan semuanya itu dengan efektif dan efisien Kepuasan Kerja adalah perasaaan positif yang dirasakan pegawai akan pekerjaannya, dimana hal tersebut akan menghasilkan sikap yang positif dan baik untuk perusahaan. Berikut ini penjabaran butir pertanyaan setiap variabel

Tabel 4 Penjabaran Variabel, Butir Kuisioner dan Skala Pengukuran

\begin{tabular}{|c|c|c|}
\hline $\begin{array}{c}\text { Variabel } \\
\text { Independen }\end{array}$ & Indikator & Skala \\
\hline $\begin{array}{l}\text { Stress Kerja } \\
\text { (X1) }\end{array}$ & $\begin{array}{l}\text { 1. Kualitas pekerjaan } \\
\text { 2. Rekan kerja } \\
\text { 3. Tuntutan } \\
\text { 4. Bosan dengan pekerjaan } \\
\text { 5. Tidak sesuai kemampuan }\end{array}$ & Likert \\
\hline $\begin{array}{l}\text { Komitmen } \\
\text { Organisasional } \\
(\mathrm{X} 2)\end{array}$ & $\begin{array}{l}\text { 1. Keterikatan emosional } \\
\text { 2. Permasalahan Organisasi } \\
\text { 3. Kerugian } \\
\text { 4. Tetap bekerja } \\
\text { 5. Kewajiban moral }\end{array}$ & Likert \\
\hline $\begin{array}{l}\text { Kepuasan Kerja } \\
(\text { X3) }\end{array}$ & $\begin{array}{l}\text { 1. Upah } \\
\text { 2. Kesempatan promosi } \\
\text { 3. Dukungan } \\
\text { 4. Tunjangan } \\
\text { 5. Penghargaan }\end{array}$ & Likert \\
\hline $\begin{array}{l}\text { Variabel } \\
\text { Dependen }\end{array}$ & Indikator & Skala \\
\hline $\begin{array}{c}\text { Turnover } \\
\text { Intention (Y1) }\end{array}$ & $\begin{array}{l}\text { 1. Berpikir untuk keluar } \\
\text { 2. Berkeinginan untuk keluar } \\
\text { 3. } \text { Keinginan untuk meninggalkan }\end{array}$ & Likert \\
\hline
\end{tabular}

\section{HASIL PENELITIAN}

Berikut adalah hasil pengujian hipotesis dari variabel yang digunakan 


\begin{tabular}{lcc}
\multicolumn{3}{c}{ Tabel 5 Hasil pengujian hipotesis } \\
\hline \multicolumn{1}{c}{ Model } & B & Sig \\
& & \\
\hline (Constant) & 9,211 & 0.000 \\
\hline Stress Kerja & 0,124 & 0.009 \\
\hline Komitmen Organisasional & 0,027 & 0.618 \\
\hline Kepuasan Kerja & 0,039 & 0.474 \\
\hline
\end{tabular}

Berdasarkan tabel pengujian hipotesis, dapat disimpulkan bahwa terdapat pengaruh stress kerjaterhadap turnover intention. Tidak terdapat pengaruh komitmen organisasional terhadapturnover intention, dan tidak terdapat pengaruh komitmen organisasional terhadap turnover intention.

\section{PENUTUP}

Berdasarkan hasil penelitian dan pembahasan yang telah diuraikan dan dikembangkan, maka penulis dapat membuat kesimpulan sebagai berikut: terdapat pengaruh stress kerja terhadap turnover intention. Hasil ini ini sejalan hasilnya dengan penelitian yang dilakukan oleh Ni Made Tiya Jumani Monica (2017), Mosahegard (2012), Shazad et al (2011) dengan objek yang berbeda. Tidak terdapat pengaruh komitmen organisasional terhadap turnover intention. Hasil ini sejalan dengan hasil penelitian sebelumnya yang dilakukan oleh Muhammad Rizwan et al (2014) dengan objek yang berbeda. Tetapi di temukan hasil yang berbeda pada penelitian Ni Made Tiya Jumani (2017), Jehanzeb et al (2013), Putri Rarasanti (2016) dengan objek yang berbeda. Tidak terdapat pengaruh kepuasan kerja terhadap turnover intention. Hasil ini mendukung hasil penelitian sebelumnya oleh Muhammad Rizwan et al (2014) dengan objek yang berbeda. Tetapi di temukan hasil yang berbeda

\section{REFRENSI:}

Angerer, Peter. Christiane Degen, and Jian Li. 2015. Physicians' intention to leave direct patient care: an integrative review. Dissertation,

Daft, Richard L. 2015. New Era of Management, 11th edition. Australia: Thomson South-Western.

Gaol, Jimmy L. 2015.A to Z Human Capital Manajemen Sumber Daya Manusia. Jakarta: Kompas Gramedia.

Haryanto, Wahyu Dwi.2014. Pengaruh Stress Kerja Dan Motivasi Terhadap Kepuasan Kerja: Hasil dari Fakultas Ekonomika dan Bisnis Universitas Diponegoro.

Jehanzeb, Khawaja., Anwar Rasheed., and Mazen F Rasheed. 2013. Organizational Commitment and Turnover Intentions: Impact of Employee's Training in Private Sector of Saudi Arabia. International Journal of Business\& Management, 8(8): 79-90.

Mosadeghrad, A.M. 2012. "A study of relationship between job stress, quality of working life and turnover intention among hospital employees". Human Resource Management International Digest, 20(3): 77-100.

Putri Rarasanti, Ida Ayu., dan I Wayan Suana. 2016. Pengaruh Job Embeddedness, Kepuasan Kerja, dan Komitmen Organisasional Terhadap Turnover Intention Karyawan. E-Jurnal Manajemen Unud, 5(7): 46904718.

Rizwan, Muhammad. Muhammad Qadeer Arshad, Hafiz Muhammad Atif Munir, Faisal Iqbal, and Atta Hussain. 2014. Determinants of employees intention to leave a study from pakistan: Result from Macrothink Institute. International Journal of Human Resource Studies Vol.4, No.3,

Robbins, Stephen P. Timothy A. Judge. 2015. Organizational Behavior, 16th edition. The United States of America: Pearson. 
Sinambela, Lijan Poltak. 2016. Manajemen Sumber Daya Manusia: Membangun Tim Kerja yang Solid Untuk Meningkatkan Kinerja, cetakan pertama. Jakarta: Bumi Aksara.

Sunyoto, Danang. 2015. Manajemen dan Pengembangan Sumber Daya Manusia, edisi pertama. Yogyakarta: CAPS. 